\title{
MENGENALKAN HURUF ABJAD PADA ANAK TUNA GRAHITA RINGAN DENGAN METODE PEMBELAJARAN VISUOMOTOR
}

\author{
Umi Salma Fauziyah ${ }^{1}$, Aninditya Sri Nugraheni ${ }^{2}$ \\ 19204080005@ student.uin-suka.ac.id ${ }^{1,}$ Aninditya@uinsuka.ac.id ${ }^{2}$ \\ Universitas Islam Negeri Sunan Kalijaga Yogyakarta ${ }^{1}$
}

\begin{abstract}
Abstrak: Tujuan dari penelitian ini adalah untuk memberikan upaya penyelesaian masalah yang muncul pada anak tunagrahita ringan berkaitan dengan kesulitan mempelajari huruf abjad. Metode penelitian yang digunakan penulis yaitu kajian literatur yang sumber datanya berasal dari kajian yang berhubungan dengan penelitian ini baik dari karya ilmiah, hasil penelitian, buku-buku dan sumber data tambahan yang berasal dari hasil observasi. Hasil yang diperoleh dari penelitian ini yaitu kegiatan belajar mengenal huruf abjad menggunakan metode visuomotor yang merupakan gabungan dari penggunaan kemampuan visual dan motoric yang dimiliki anak tuna grahita ringan. Metode pembelajatan visumotor ini diawali dari mengenal nama dan suara huruf, kemudian gambar visual dari masing-masing huruf, dan dilanjutkan dengan pemanfaatan kemampuan motorik anak untuk menuliskan huruf-huruf tersebut maupun menggambar bentuk-bentuk huruf tersebut menggunakan anggota tubuhnya.
\end{abstract}

Kata kunci: metode visuomotor, mengenalkan huruf abjad, tuna grahita ringan

\section{INTRODUCE ALPHABET LETTERS TO MILD MENTALLY RETARDED CHILDREN USING VISUOMOTOR LEARNING METHOD}

\begin{abstract}
The purpose of this study is to provide efforts to solve problems that arise in mild retarded children related to the difficulty of learning the letters of the alphabet. The research method used by the author is a literature review whose data sources come from studies related to this research both from scientific work, research results, and books and additional data sources derived from observations. The results obtained from this study are learning activities to recognize the letters of the alphabet using the visuomotor leraning method which is a combination of the use of visual and motor skills possessed by children with mild mental disabilities. This visumotor learning method starts from knowing the names and sounds of letters, then visual images of each letter, and continues with the use of the child's motor skills to write the letters and draw the shape of the letters using their limbs.
\end{abstract}

Keywords: visuomotor learning method, introducing letters of the alphabet, mild mentally retarded children

PENDAHULUAN 
Umi, Aninditya. Mengenalkan Huruf Abjad Pada...

Penelitian ini dilatar belakangi dari hasil observasi yang dilakukan penulis di SDN Giwangan khususnya pada anak-anak berkebutuhan khusus yang bersekolah di SDN Giwangan yang didapat dari hasil wawancara dengan guru pendamping anak berkebutuhan khusus yang ditugaskan di sekolah. Berkaitan dengan hambatan pembelajaran khususnya pada mata pelajaran bahasa Indonesia terdapat masalah yang muncul yaitu dari anak tunagrahita. Terdapat anak tunagrahita yang mengalami kesulitan untuk mengenal huruf-huruf abjad, padahal sebagaimana yang diketahui bahwa salah satu dasar pemerolehan informasi yaitu dengan membaca. Jika anak tidak dapat mengenali huruf dengan baik maka besar kemungkinan anak tersebut tidak dapat membaca dan pemerolehan informasinya kurang.

Hal itu sejalan dengan yang diungkapkan oleh Hayat dan Yusuf bahwa bahasa adalah medium bagi siswa untuk mengembangkan dan memberdayakan diri pribadinya. Melalui bahasa, siswa membentuk dan mengisi substansi pikirannya, tumbuh dan berkembang sambil berinteraksi dengan sekelilingnya, dan membentuk realitas kepribadiannya. Salah satu dasar dari pemahaman bahasa yang mahir yaitu dengan memahami huruf-hurufnya, dan masalah yang muncul ini menjadi salah satu hal yang perlu dicari solusinya (Hayat \& Suhendra, 2010, p. 38).

Sebagaimana di atas sudah disinggung mengenai pentingnya memahami huruf sebagai bekal penting bagi anak untuk mengembangkan literasi membaca dan menulis. Maka terdapat empat keterampilan berkaitan dengan pengetahuan terhadap huruf yang juga mempengaruhi literasi: 1) pengenalan huruf, yaitu kemampuan untuk mengenal bentuk dari huruf; 2) penamaan huruf, yaitu menghubungkan bentuk dari huruf dengan namanya; 3) pengetahuan tentang suara huruf, yaitu menemukan kemiripan suara dengan bentuk atau nama dari huruf; 4) tulisan huruf, yaitu kemampuan untuk meniru huruf dengan alat tulis berdasarkan kesesuaian dengan bentuk dan peritah (Puranik, Petscher, \& Lonigan, 2014).

Mengenali huruf membuat anak lebih mudah untuk mengingat dan membedakan tampilan antar huruf. Selain mengenal tampilannya, ada keterkaitan yang juga penting dari bagian keterampilan awal dalam mengenali huruf, yaitu kaitan antara nama huruf dan suara huruf karena pembelajaran mengenal nama huruf dapat mendukung pembelajaran tentang suara huruf yang pada akhirnya juga mampu meningkatkan kemampuan ejaan fonetik. Keterampilan terakhir tentang tulisan huruf ini memiliki 
Umi, Aninditya. Mengenalkan Huruf Abjad Pada...

kaitan erat dengan visualisasi huruf tersebut yang kemudian melalui visualisasi ini huruf-huruf dapat disimpan di memori anak, ini menjadi tahap awal untuk mulai mengenali huruf. Sisi lainnya tentang menulis huruf yaitu mengenai gerakan yang dilakukan anak untuk menulis bentuk huruf, karena gerakan ketika menulis bentuk huruf dapat meningkatkan memori terhadap bentuk huruf tersebut.

Berdasarkan penjelasan tersebut, dapat ditarik kaitan antara keterlibatan system visual dan motoric dalam upaya mengenalkan huruf pada anak. Simulasi motoric mental ini mempercepat pengenalan secara visual bahkan pada penamaan objek-objek. Gambaran visual dari huruf berkaitan dengan fungsi motoric ketika anak melakukan gerakan menulis. Selain itu, gerakan motoric juga dapat meningkatkan daya tangkap terhadap huruf karena anak mendapat pengalaman menggarakkan tangannya ketika membuat bentuk-bentuk huruf.

Berdasarkan penelitian yang dilakukan oleh Deborah Zemlock dkk. pada anakanak yang baru belajar mengenal huruf dengan kisaran umur 3-6,5 tahun di Amerika, hasilnya menunjukkan adanya peningkatan pemahaman terhadap huruf melalui penerapan metode visual-motorik (Zemlock, Vinci-Booher, \& James, 2018).

Hal serupa diungkapkan oleh Wahyuni dan Nisa bahwa kegiatan fisik dapat menjadi salah satu upaya untuk meningkatkan fungsi kognitif pada seseorang. Fungsi kognitif merupakan fungsi kompleks pada otak manusia yang melibatkan aspek memori, baik jangka panjang, perhatian, fungsi perencanaan dan nalar serta fungsi strategi dalam berpikir dari seseorang. Fungsi kognitif juga melibatkan aspek kognitif seperti bahasa dan perbendaharaan kata (Wahyuni \& Nisa, 2016).

Sebagaimana anak-anak lain, anak penderita tunagrahita memiliki hak-hak yang sama seperti anak normal dan juga kebutuhan-kebutuhan tertentu yang hendaknya dipenuhi agar mereka tumbuh menjadi manusia total yang terintegrasi. Berkaitan dengan pembelajaran anak tunagrahita sendiri, metode pembelajaran yang diberikan perlu mempertimbangkan tingkatan anak tunagrahita itu sendiri. Meski demikian tetap saja untuk setiap klasifikasi tuna grahita dibutuhkan metode pembelajaran yang sesuai dan memberikan penekanan pada aspek keterampilan.

Metode pembelajaran yang kemudian akan diterapkan pada anak tuna grahita ringan salah satunya yaitu yang berkaitan dengan jenis instruksi sistematik. Bentuk instruksi ini dapat bersifat verbal, gerakan, fisik, ataupun peniruan (Rahmawati, 2012). 
Umi, Aninditya. Mengenalkan Huruf Abjad Pada...

Berkaitan dengan cara belajar anak tuna grahita tersebut maka ada kaitan antara pemberian instruksi secara verbal dan gerakan fisik dengan metode pembelajaran yang mengintegrasikan visual dan motorik untuk meningkatkan kemampuan anak tuna grahita dalam mengenal huruf abjad. Karena dalam metode pembelajaran visuomotor ini anak-anak diharapkan mampu mengoptimalkan fungsi visual motoriknya untuk belajar mengenali huruf abjad, meski memiliki IQ yang rendah anak tuna grahita ringan ini dapat melakukan gerakan motoric dengan instruksi (Widiastuti \& Winaya, 2019).

Demikian, penyusun mengharapkan efek dari integrasi kegiatan yang berbeda antara kemampuan visual dan motorik dapat meningkatkan kemahiran anak tuna grahita dalam mengenali huruf abjad. Kedua kegiatan ini berfokus pada instruksi langsung (nama huruf, bentuk huruf, dan cara meniru huruf), tetapi masing-masing memiliki perbedaan dalam cara mengeksplorasi huruf. Penyusun memperkirakan bahwa program pelatihan visual-motorik dengan melibatkan anggota tubuh akan lebih efisien daripada hanya melakukan eksplorasi visual dari huruf. Penyusun berasumsi bahwa intervensi ini akan meningkatkan representasi visual dari huruf-huruf yang kemudian dapat berdampak positif pada cara belajar menulis.

\section{METODE PENELITIAN}

Penelitian ini menggunakan pendekatan kualitatif deskriptif dengan metode penelitian studi literatur. Peneliti melakukan studi terhadap karya tulis yang berkaitan dengan riset ini, sumber data utama riset ini berasal dari karya ilmiah yang telah diterbitkan, hasil penelitian, dan buku-buku. Selain data primer yang menjadi sumber utama, riset ini juga memasukkan data pendukung yang berasal dari hasil observasi di sekolah. Kedua sumber data tersebut kemudian digabungkan dan diambil hasil dan kesimpulannya (Zed, 2014, p. 3).

\section{Gambar 1. Alur Penelitian Studi Literatur}

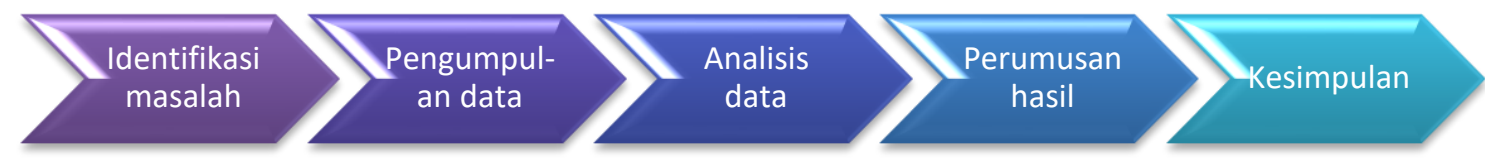

Sumber: http://repository.uin-suska.ac.id/3506 


\section{Umi, Aninditya. Mengenalkan Huruf Abjad Pada...}

Tahap identifikasi masalah dilakukan pada awal penelitian melalui observasi dan wawancara dengan guru pendamping khusus yang ada di SDN Giwangan mengenai kesulitan belajar yang dialami anak berkebutuhan khusus terkait mata pelajaran Bahasa Indonesia.

Teknik pengumpulan data adalah cara yang dilakukan peneliti guna mencari dan menemukan data yang dibutuhkan pada saat penelitian (Sugiyono, 2014, p. 401). Pengumpulan data penelitian ini diperoleh dari kajian pustaka seperti jurnal, buku, dan hasil penelitian yang berkaitan dengan anak berkebutuhan khusus lebih fokus pada anak tuna grahita, kemudian mengenai pemahaman terhadap huruf abjad, dan penggunaan metode visuomotor.

Pada tahap analisis data penyusun menganalisis data yang memiliki keterkaitann dengan penelitian seperti kategori dan kemampuan belajar anak tuna grahita, aspekaspek yang berkaitan dengan pemahaman huruf, dan langkah-langkah metode visuomotor.

Tahap perumusan hasil merupakan tahap perumusan solusi untuk menjawab masalah yang muncul, pada tahap ini penyusun merumuskan metode visuomotor sebagai upaya pengenalan huruf bagi anak tuna grahita.

Kesimpulan penelitian ini berkaitan dengan hasil akhir yang didapat dari penelitian, bahwa metode visuomotor ini dapat diterapkan pada anak tuna grahita ringan dan bisa digunakan untuk kegiatan pembelajaran pengenalan huruf.

\section{HASIL DAN PEMBAHASAN}

Pendidikan menjadi suatu hal yang penting bagi kehidupan manusia, karena dengan pendidikan seseorang dapat membentuk dirinya menjadi lebih baik dari sebelumnya. Indonesia telah mengatur pendidikan bagi masyarakat yaitu dalam Undang-Undang Dasar Negara Republik Indonesia tahun 1945 pasal 31 ayat (1) disebutkan bahwa setiap warga negara berhak mendapat pendidikan, dan ayat (3) menegaskan bahwa pemerintah mengusahakan dan menyelenggarakan satu system pendidikan nasional yang meningkatkan keimanan dan ketakwaan serta akhlak mulia dalam rangka mencerdaskan kehidupan bangsa yang dengan Undang-Undang. Berdasarkan hal tersebut maka setiap warga Negara Indonesia berhak mendapat pendidikan termasuk anak berkebutuhan khusus. 
Umi, Aninditya. Mengenalkan Huruf Abjad Pada...

Salah satu anak berkebutuhan khusus adalah anak tuna grahita. Tunagrahita merupakan seseorang yang memiliki hambatan kecerdasan, lebih lanjut Kustswan menjelaskan bahwa anak tuna grahita merupakan anak yang memiliki kecerdasan dibawah rata-rata yaitu IQ nya dibawah angka 70 atau 68. Selain kecerdasan (IQ) yang dibawah rata-rata, anak-anak ini juga memiliki ketidakmampuan melakukan adaptasi perilaku yang muncul pada masa perkembangan. Ia juga mengatakan bahwa anak dengan kelainan tuna grahita mempunyai hambatan akademik yang cukup menonjol (Sari, Binahayati, \& T, 2017).

Berkaitan dengan ABK khususnya tunagrahita, terdapat empat kategori pengelompokan yaitu 1) ringan; 2) sedang; 3) berat; 4) sangat berat. Tunagrahita ringan adalah seseorang yang memiliki IQ berkisar antara 55 sampai dengan 69. Mereka umumnya lancar berbicara tetapi perbendaharaan katanya terbatas. Mereka masih dimungkinkan untuk mengikuti pelajaran akademik walaupun tingkatannya masih sederhana. Secara umum tingkat kecerdasan yang mampu dicapai anak tuna grahita hanya mencapai usia 12 tahun.

Tuna grahita sedang memiliki tingkat kecerdasan (IQ) yang berkisar pada angka 40 sampai 54. Secara umum mereka hampir tidak mampu mempelajari materi-materi akademik seperti membaca, menulis dan berhitung. Cara mereka belajar cenderung meniru apa yang disampaikan orang lain, selain itu perkembangan bahasanya juga lebih terbatas dibanding anak tuna grahita ringan. Perkembangan kecerdasan maksimalnya hanya setara dengan anak usia 7 tahun.

Tuna grahita berat memiliki tingkat kecerdasan (IQ) yang berkisar antara angka 25 sampai 39. Segala aktivitas yang dilakukannya cenderung bergantung pada pertolongan orang lain, jadi mereka tidak mampu merawat dirinya sendiri seperti makan, berpakaian, mandi, dan lainnya. Karena hal ini mereka yang berada pada tahap berat tidak diharapkan untuk mampu berpartisipasi di lingkungannya.

Tuna grahita sangat berat memiliki tingkat kecerdasan (IQ) yang kurang dari angka 25. Kondisi mereka umumya hampir sama seperti terbelakang mental berat. Dalam banyak kajian, mereka yang terbelakang mental berat dan sangat berat sering diilustrasikan sama. Perkembangan maksimal kecerdasannya hanya setara dengan anak normal yang berusia 3 atau 4 tahun (Supena, 2017). 
Umi, Aninditya. Mengenalkan Huruf Abjad Pada...

Tabel 1. Klasifikasi Tingkat Kecerdasan

\begin{tabular}{|c|c|}
\hline Kategori & Tingkat IQ \\
\hline Tua grahita ringan $($ mild $)$ & Berkisar di angka 55-69 \\
\hline Tuna grahita sedang $($ moderate $)$ & Berkisar di angka $40-54$ \\
\hline Tuna grahita berat $($ severe $)$ & Berkisar di angka $25-39$ \\
\hline Tuna grahita sangat berat (profound) & Angkanya $<22$ \\
\hline
\end{tabular}

Sumber: (Kurniawan, Saichudin, \& Kinanti, 2018)

Karena keterbatasan yang dialami sebagaimana sudah dijabarkan di atas maka anak dengan tuna grahita ini perlu mendapat penanganan khusus berkaitan dengan pembelajarannya di kelas, termasuk berkaitan dengan literasi membaca dan menulis yang diawali dari mengenali huruf-huruf abjad. Jika sepenuhnya disamakan dengan anak normal maka besar kemungkinan mereka akan tertinggal dalam banyak mata pelajaran.

Literasi membaca dan menulis ini perlu adanya pembiasaan baik untuk anak normal maupun anak tuna grahita karena tidak bisa secara tiba-tiba anak menjadi mahir membaca dan menulis terlebih lagi pada anak tuna grahita. Sebagaimana disinggung di atas bahwa anak tuna grahita ringan memiliki tingkat kecerdasan dibawah rata-rata pada umunya, maka kegiatan pembelajaran yang digunakan juga perlu pengembangan menyesuaikan anak tersebut.

Selain keterbatasan tingkat kecerdasan yang dimiliki oleh anak tuna grahita, perlu juga dipahami mengenai prinsip-prinsip khusus dalam layanan yang sesuai dengan anak tuna grahita (Widiastuti \& Winaya, 2019), antara lain:

1. Bahasa yang digunakan

Bahasa yang digunakan ketika berinteraksi dengan anak tuna grahita disarankan menggunakan bahasa yang sederhana, tidak berbelit, jelas, dan menggunakan katakata yang sering didengar oleh anak.

2. Kecekatan motorik

Anak tuna grahita mampu memepelajari sesuatu dengan cara melakukannya. Di lain sisi, upaya ini dapat melatih anak utamanya untuk melakukan gerakan yang kurang terbiasa dikuasainya.

3. Keperagaan

Prinsip ini digunakan untuk mengajar anak tuna grahita berkaitan dengan adanya keterbatasan pada anak-anak ini dalam berpikir abstrak. Oleh karena itu perlu 
Umi, Aninditya. Mengenalkan Huruf Abjad Pada... menggunakan alat peraga agar anak tuna grahita ini tidak verbalisme, dan memiliki tanggapan mengenai apa yang mereka pelajari.

4. Pengulangan

Karena anak tuna grahita memiliki kelemahan yaitu cepat lupa dengan hal-hal yang baru dipelajari maka dalam mengajar mereka membutuhkan pengulanganpengulangan disertai contoh yang beragam.

Kemampuan dasar yang perlu dipahami setiap anak tanpa terkecuali anak tuna grahita diantaranya membaca, menulis, dan berhitung karena ini merupakan kemampuan dasar yang perlu dimiliki. Kemampuan membaca dan menulis tidak dapat berkembang jika anak belum mengenal huruf. Carol \& Barbara menjelaskan bahwa kemampuan mengenal huruf merupakan kemampuan untuk mengenal sesuatu melalui ciri-ciri atau tanda-tanda aksara dalam struktur tulisnya yang merupakan bagian dari abjad yang melambangkan bunyi dari bahasa (Seefeldt \& A., 2008, p. 330).

Lebih lanjut Bromley berpendapat bahwa bahasa merupakan sistem simbol yang runtut guna mentransfer berbagai pokok pikiran atau informasi yang bisa berupa simbol-simbol visual maupun verbal (Dhieni, Fridani, Muis, \& Yarmi, 2014, p. 1.14). Berdasarkan ungkapan yang disampaikan maka dapat dipahami bahwa upaya mengenal huruf juga sebuah upaya mengenal simbol, dalam mengenal huruf maka simbol ini direpresentasikan dalam bentuk huruf itu sendiri.

Berkaitan dengan ini maka penting anak-anak tuna grahita dapat belajar mengenal huruf dimulai dengan mengenal simbol dan bentuk visualnya, kemudian memahami struktur tulisnya, dengan tetap memperhatikan hal-hal yang berkaitan dengan kemampuan anak tuna grahita itu sendiri termasuk prinsip-prinsip khusus dalam layanan yang sesuai.

Jika meninjau tingkat kecerdasan anak tuna grahita yang berada di bawah rata-rata dan mengingat prinsip-prinsip khusus dalam layanan yang sesuai dengan anak tuna grahita maka kegiatan pembelajaran mengenalkan huruf yang menerapkan kegiatan gerak motorik dapat dijadikan sebagai referensi untuk pembelajaran yang lebih bermakna pada anak tuna grahita, karena juga mengingat anak-anak ini mudah lupa dengan hal yang baru dipelajari. Berkaitan dengan hal ini, penulis merumuskan metode yang menggunakan kemampuan visual dan motorik untuk membuat anak lebih mampu memahami huruf-huruf abjad. 
Umi, Aninditya. Mengenalkan Huruf Abjad Pada...

Metode pembelajaran visuomotor merupakan gabungan antara presepsi visual dengan gerak motoric yang dilakukan oleh anak dalam belajar menganal huruf dengan cara menuliskannya, baik dengan alat tulis maupun menggunakan seluruh anggota badannya. Melalui metode pembelajaran ini anak mendapat gambaran visual mengenai huruf yang dipelajarinya dan merasakan bentuk-bentuk huruf bukan hanya dari gerakan tangan tapi juga dengan anggota badannya (Bara \& Bonneton-Botté, 2018).

Berikut penyusun menyajikan langkah-langkah yang perlu ditempuh untuk menerapkan metode pembelajaran visuomotor guna meningkatkan pengetahuan anak tuna grahita ringan terhadap huruf (Bara \& Bonneton-Botté, 2018):

\section{Gambar 2. Langkah-langkah Metode Pembelajaran Visuomotor}

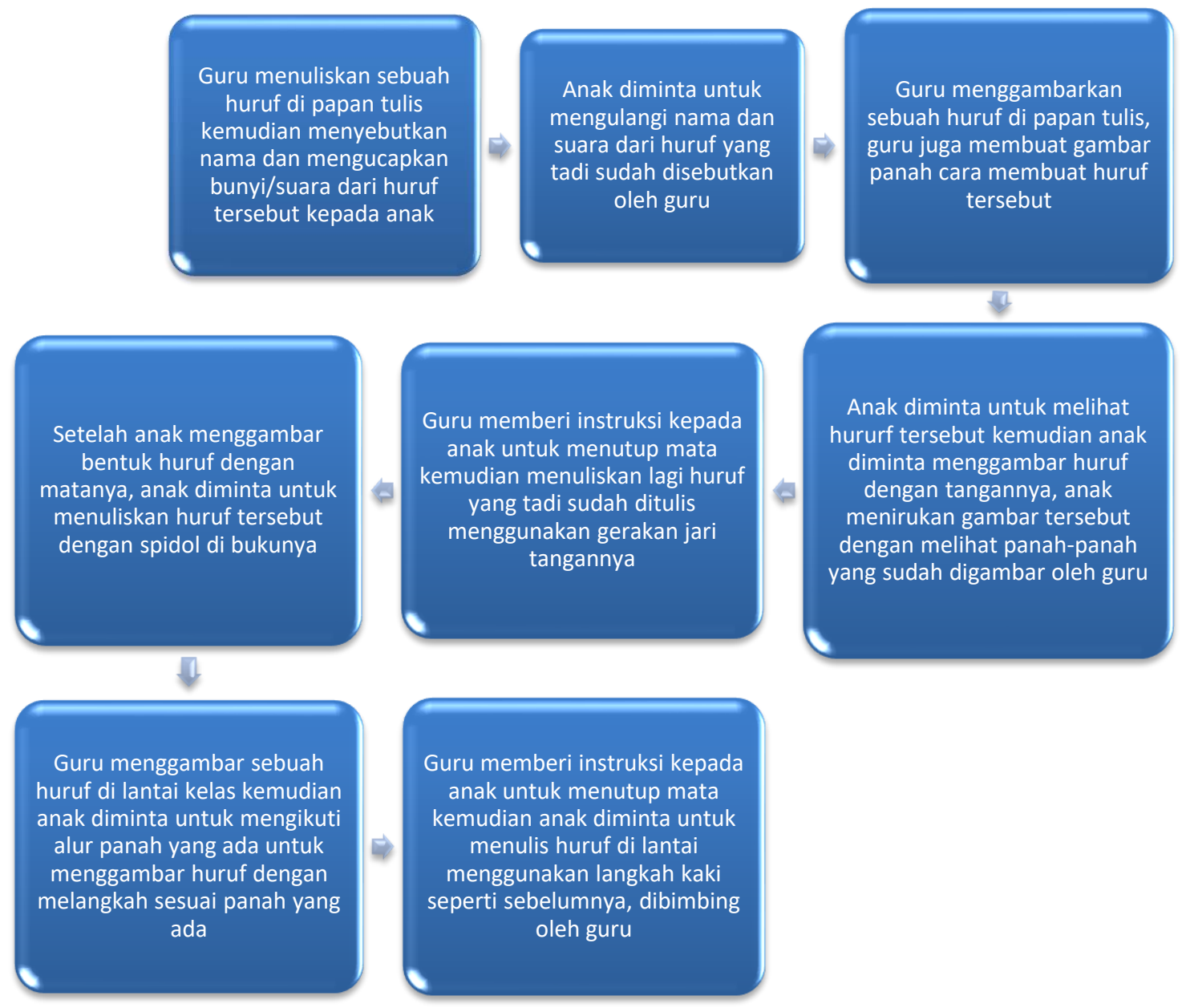

Sebagai contoh guru akan mengenalkan huruf A kepada anak, tahap satu guru mengenalkan tulisan huruf A pada papan tulis atau bisa juga pada buku tulis anak agar 
Umi, Aninditya. Mengenalkan Huruf Abjad Pada... anak melihat bentuk huruf $\mathrm{A}$ terlebih dahulu menggunakan spidol yang dapat terlihat jelas ini dilakukan karena anak tuna grahita kurang mampu dalam berpikir abstrak

Tahap dua anak diminta untuk mengulangi nama dan pelafalan huruf $\mathrm{A}$, hal ini dilakukan agar anak mengenal nama dan cara melafalkan huruf tersebut.

Tahap tiga guru membuat bentuk huruf A ditambah dengan panah cara membuatnya jika huruf A seperti pada gambar di bawah ini:

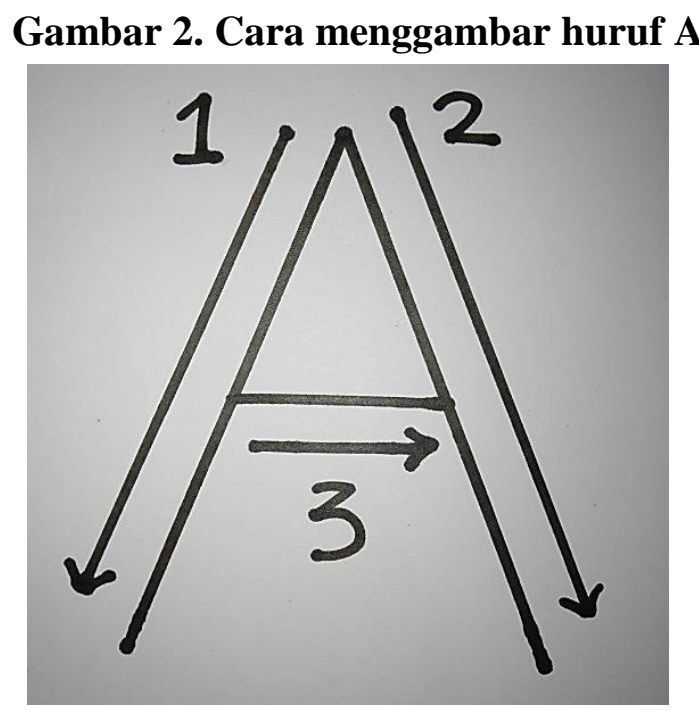

Tahap empat anak diminta untuk menirukan huruf A dengan mengikuti urutan panah yang telah di buat oleh guru, hal ini dilakukan karena anak tuna grahita kurang mampu membuat hal yang tahapannya kurang jelas.

Tahap lima anak diminta untuk menutup mata kemudian menuliskan huruf A dengan jari seperti yang dilakukan pada tahap keempat cara ini dilakukan untuk mengasah ingatan anak terhadap huruf yang barusaja dipelajari.

Tahap enam anak mulai menggunakan spidol untuk menulis huruf A dengan tangannya, pada tahap ini kemampuan motoric anak tuna grahita mendapat pengalaman untuk membuat bentuk huruf A yang kemudian dapat dilihat tampilan visualnya, tahap ini mencoba untuk membuat anak tuna grahita tidak berpikir abstrak dan melihat hasilnya dalam bentuk konkret yaitu bentuk huruf pada buku.

Tahap tujuh anak diminta untuk mengikuti bentuk huruf A yang telah digambar guru di lantai, kemudian anak diminta untuk melangkah mengikuti garis-garis huruf A, ini dilakukan agak anggota lain selain tangan juga dapat merasakan bentuk dari huruf yang sedang dibuat. 
Umi, Aninditya. Mengenalkan Huruf Abjad Pada...

Tahap delapan anak diminta untuk melangkah membuat bentuk huruf A dengan mata tertutup, ini dilakukan agar anak dapat lebih mengingat cara membuat huruf $\mathrm{A}$ yang baru saja dipelajarinya.

Metode pembelajaran visual motorik ini pernah diuji coba pada penelitian yang dilakukan oleh Deborah Zemlock dkk., penelitian ini menunjukkan hasil bahwa kegiatan yang melibatkan keterampilan visual motoric dan melibatkan simbol-simbol dapat meningkatkan pemahaman terhadap suatu huruf. Zemlock juga mengungkapkan bahwa tulisan tangan apapun dapat meningkatkan pemahaman terhadap huruf karena memberikan fasilitas yang menguntungkan dalam koordinasi visual motorik (Zemlock et al., 2018).

Penelitian Zemlock dkk ini dilakukan di Amerika tepatnya di Negara Bagian Indiana dengan partisipan anak-anak yang umurnya berkisar antara 3 - 6,5 tahun yang baru mulai belajar mengenal huruf. Anak-anak ini kemudian dibagi menjadi 4 kelompok yaitu menulis huruf, mengetik huruf, melihat huruf, dan melihat gambar huruf. Kelompok yang menunjukkan skor pemahaman paling baik adalah kelompok menulis huruf. Ini menunjukkan bahwa memahami huruf dengan gerakan tulis mampu memberi peningkatan daya tangkap anak-anak yang sedang belajar mengenal huruf.

Berkaitan dengan pemahaman terhadap huruf, di awal penyusun menyebutkan bahwa terdapat empat keterampilan yang perlu dikuasai dalam tahap-tahap mengenali huruf. Salah satunya yaitu menulis huruf, berdasarkan penelitian yang dilakukan oleh Simon dkk. pada anak-anak Brazil di tingkat sekolah dasar membuktikan adanya keterkaitan langsung antara kemampuan visual dan motoric dengan performa menulis dari anak-anak tersebut (Capellini, Giaconi, \& Germano, 2017).

Berdasarkan penelitian yang dilakukan oleh Simon, diperoleh data bahwa anakanak di kelas III yang mendapat skor koordinasi motoric dibawah rata-rata mungkin bisa berdampak pada perkembangan integrasi visuomotor nya tapi juga pada persepsi visualnya. Ini menjadi salah satu alasan agar kegiatan mengenal huruf menggunakan motoric perlu diterapkan, agar kemampuan visual untuk menangkap gambaran hurufnya juga bisa berkembang lebih baik, yang kemudian akan berdampak pada pemahaman huruf yang lebih baik juga.

Penelitian di atas juga sejalan dengan hasil penelitian yang dilakukan oleh Jennifer dkk. Penelitian ini menunjukkan bahwa koordinasi antara kemampuan visual, 
Umi, Aninditya. Mengenalkan Huruf Abjad Pada...

motoric, dan proses kognitif memberi kontribusi positif untuk meningkatkan perkembangan keterampilan menulis huruf abjad pada anak (Maldarelli, Kahrs, Hunt, \& Lockman, 2015). Berdasarkan hasil penelitian sebelumnya, metode pembelajaran yang menggabungkan kemampuan visual dan motorik anak diharapkan mampu meningkatkan pengetahuannya terhadap huruf-huruf abjad.

Vinci-Booher menyatakan bahwa hasil penelitiannya menunjukkan bahwa praktek menulis menyajikan keterkaitan visual dan morotik di dalam otak, lebih baik daripada belajar memahami huruf dengan mengetik (Vinci-Booher, James, \& James, 2016). Jika dipahami lebih jauh, jika kegiatan menulis huruf dengan anggota badan, misalnya tangan dapat memberikan keterkaitan lebih baik daripada hanya belajar memahami huruf dengan melihat simbol visual maka menulis dengan melibatkan anggota tubuh dapat memberikan memori lebih baik pada otak mengenai huruf yang dipelajari oleh anak-anak.

Wahyuni dan Nisa juga menyebutkan bahwa kegiatan fisik dapat menjadi salah satu upaya untuk meningkatkan fungsi kognitif pada seseorang. Hal ini terjadi karena kegiatan fisik berkaitan langsung dengan perbaikan penyesuaian atau adaptasi dari selsel otak dan fungsi kognitif seseorang. Sebagaimana sudah disinggung di depan bahwa fungsi kognitif merupakan fungsi kompleks pada otak manusia yang melibatkan aspek memori, baik jangka panjang, perhatian, fungsi perencanaan dan nalar serta fungsi strategi dalam berpikir dari seseorang. Fungsi kognitif juga melibatkan aspek kognitif seperti bahasa dan perbendaharaan kata (Wahyuni \& Nisa, 2016).

Hasil penelitian menunjukkan bahwa ada dampak yang positif mengenai penggunaan metode pembelajaran visuomotor terhadap kemampuan anak-anak dalam memahami huruf, karena kegiatan menulis dengan anggota tubuh yang terintegrasi dengan presepsi visual mampu memberikan pemahaman yang lebih baik dan meningkatkan daya tangkap anak-anak yang sedang belajar mengenal huruf.

Penelitian selanjutnya mungkin bisa lebih jauh menyelidiki tentang peran gerakan lengan dan anggota tubuh dalam metode pembelajaran visuomotor ini. Penelitian di masa yang akan datang mungkin juga dapat meneliti pentingnya berbagai ukuran huruf, dalam hal ini berkaitan dengan motorik kasar, karena keberagaman diketahui meningkatkan kinerja dalam berbagai hal mengenai pembelajaran motoric. 
Umi, Aninditya. Mengenalkan Huruf Abjad Pada...

\section{SIMPULAN}

Berdasarkan hasil penyajian data dan pembahasan, maka diketahui bahwa optimalisasi dari kemampuan visual dan motorik ini perlu dilakukan untuk lebih meningkatkan keterampilan anak tuna grahita ringan dalam memahami huruf-huruf. Sebagaimana yang diketahui bahwa untuk menyampaikan materi pelajaran pada anak tuna grahita ringan, kegiatan pembelajaran perlu diperbaharui agar lebih sederhana. Begitupun metode pembelajaran visuomotor ini disajikan sesederhana mungkin agar anak tuna grahita ringan ini dapat memahami huruf lebih baik.

\section{UCAPAN TERIMA KASIH}

Penyusun mengucapkan terimakasih kepada orang tua yang telah memberikan dukungan moril maupun materiil, kepada dosen pembimbing yang telah memberikan bimbingan kepada penyusun agar penelitian ini dapat optimal, kemudian kepada guru dan staf SDN Giwangan Kota Yogyakarta yang telah memberikan tempat untuk penelitian, dan semua pihak yang memberikan dukungan serta saran sehingga penelitian ini dapat berjalan dengan baik dan lancar.

\section{DAFTAR RUJUKAN}

Bara, F., \& Bonneton-Botté, N. (2018). Learning Letters With the Whole Body:

Visuomotor Versus Visual Teaching in Kindergarten. Perceptual and Motor Skills, 125(1), 190-207. https://doi.org/10.1177/0031512517742284

Capellini, S. A., Giaconi, C., \& Germano, G. D. (2017). Relation between Visual Motor Integration and Handwriting in Students of Elementary School. Psychology, 08(02), 258-270. https://doi.org/10.4236/psych.2017.82015

Dhieni, N., Fridani, L., Muis, A., \& Yarmi, G. (2014). Metode Pengembangan Bahasa. Jakarta: Universitas Terbuka.

Hayat, B., \& Suhendra, Y. (2010). Benchmark Internasional Mutu Pendidikan. Jakarta: PT Bumi Aksara.

Kurniawan, B., Saichudin, \& Kinanti, R. G. (2018). Survei Kekuatan Otot Kaki pada Anak Tuna Grahita di SLB Eka Mandiri Kota Batu Malang. Jurnal Sport Science, $7(1)$.

Maldarelli, J. E., Kahrs, U. A., Hunt, U. C., \& Lockman, J. J. (2015). Development of Early Handwriting: Visual - Motor Control during Letter Copying. Development Psychology, 51(7), 879-888. https://doi.org/10.1037/a0039424.Development 
Umi, Aninditya. Mengenalkan Huruf Abjad Pada...

Puranik, C. S., Petscher, Y., \& Lonigan, C. J. (2014). Learning to Write Letters: Examination of Student and Letter Factors. Journal of Experimental Child Psychology, 128, 152-170. https://doi.org/10.1016/j.jecp.2014.07.009.Learning

Rahmawati, S. W. (2012). Penanganan anak tunagrahita (Mental Retardation) dalam Program Pendidikan Khusus. Jurnal Psiko Utama, 1(1), 1-23. Retrieved from https://www.researchgate.net

Sari, S. F. M., Binahayati, \& T, B. M. (2017). Pendidikan Bagi Anak Tuna Grahita (Studi Kasus Tunagrahita Sedang Di Slb N Purwakarta). Jurnal Penelitian Dan Pengabdian Kepada Masyarakat, 4(2), 217-222. https://doi.org/10.24198/jppm.v4i2.14273

Seefeldt, C., \& A., W. B. (2008). Pendidikan Anak Usia Dini: Menyiapkan Anak Usia Tiga, Empat dan Lima Tahun Masuk Sekolah. Jakarta: Indeks.

Sugiyono. (2014). Metode Penelitian Kuantitatif dan R\&D. Bandung: Alfabeta.

Supena, A. (2017). Model Pendidikan Inklusif untuk Siswa Tunagrahita di Sekolah Dasar. Jurnal Parameter, 29(2), 145-155.

Vinci-Booher, S., James, T. W., \& James, K. H. (2016). Visual - Motor Functional Connectivity in Preshool Children Emerges After Handwriting Experience. Trend in Neuroscience and Education, 5(3), 107-120.

Wahyuni, A., \& Nisa, K. (2016). Pengaruh Aktivitas dan Latihan Fisik terhadap Fungsi Kognitif pada Penderita Demensia. Jurnal Majority, 5(4), 12-16.

Widiastuti, N. L. G. K., \& Winaya, I. M. A. (2019). Prinsip Khusus Dan Jenis Layanan Pendidikan Bagi Anak Tunagrahita. Jurnal Santiaji Pendidikan (JSP), 9(2), 116126. https://doi.org/10.36733/jsp.v9i2.392

Zed, M. (2014). Metode Penelitian Kepustakaan. Jakarta: Yayasan Obor Indonesia.

Zemlock, D., Vinci-Booher, S., \& James, K. H. (2018). Visual-Motor Symbol Production Facilitates Letter Recognition in Young Children. Reading and Writing, 31(6), 1255-1271. https://doi.org/10.1007/s11145-018-9831-z 